\title{
Assessment of Treatment Volume Definition for Irradiation of Spinal Ependymomas: an Original Article
}

\author{
Ferrat Dincoglan, Murat Beyzadeoglu, Selcuk Demiral, Omer Sager ${ }^{*}$ \\ Department of Radiation Oncology; University of Health Sciences, Gulhane Medical Faculty, Ankara, Turkey \\ *Corresponding Author: Omer Sager, Department of Radiation Oncology; University of Health Sciences, \\ Gulhane Medical Faculty, Ankara Turkey.
}

\begin{abstract}
Background: Ependymomas may arise from the spinal cord or the cranial ventricular system and constitute a heterogeneous group of central nervous system (CNS) tumors. Spinal epandymomas are mostly low grade tumors with an indolent disease course.However, symptomatic presentation may occur in some patients. Irradiation may play an integral role in management particularly as a complementary treatment modality.Definition of treatment volumes for irradiation of spinal ependymomas have been poorly addressed in the literature. In this context, we assessed the incorporation of multimodality imaging with magnetic resonance imaging (MRI) in treatment volume definition for irradiation of spinal ependymomas in this original research article.
\end{abstract}

Materials and Methods: Irradiation target volume definition based on multimodality imaging with incorporation of MRI or by use of the Computed Tomography (CT)-simulation images only was comparatively evaluated for patients with spinal ependymoma.

Results and Conclusion: Thorough evaluation was performed for lesion size, location, patient symptomatology and preferences along with expected treatment outcomes on an individual basis. Comparative assessment of irradiation treatment volume determination by CT-only imaging and by CT-MR fusion based imaging revealed that ground truth target volume outlined by the board-certified radiation oncologists was identical to target definition by use of CT-MR fusion based imaging. In conclusion, treatment volume determination composes an important part of irradiation for spinal ependymomas. Incorporation of MRI into the treatment volume definition process for precise radiation treatment planning for spinal ependymomas may be utilized to achieve improved outcomes, nevertheless, further study is required to shed light on this critical issue.

Keywords: Spinal Ependymoma, Irradiation, Magnetic Resonance Imaging (MRI)

\section{INTRODUCTION}

Primary spinal cord tumors are mostly ependymomas and astrocytomaswhich may be treated primarily by surgery as the traditional treatment modality and irradiation as an adjunctive, salvage or primary treatment in selected patients. [1-11]Ependymomas may arise from the spinal cord or the cranial ventricular system and constitute a heterogeneous group of central nervous system (CNS) tumors which may be observed in both the pediatric and adult population. Spinal epandymomas are mostly low grade tumors with an indolent disease course. World Health Organization (WHO) classification includes 3 grades of epandymomas with regard to degree of malignancy detected by microscopy. [12] WHO grade I lesions include myxopapillary ependymoma and subependymoma.[12]WHO grade II lesions include classic, papillary, cellular, tanycytic, and clear cell subtypes with similar biological behaviour and without anaplastic characteristics. [12] WHO grade III lesions are anaplastic ependymomas with most malignant behaviour. [12] Resectability, locations, and recurrence tendencies show diversities between WHO grade I, II, and III ependymomas. Majority of lesions occurring in the spinal cord include the WHO grade II classic ependymoma and most frequent location is the cervical or thoracal region.

Magnetic resonance imaging (MRI) is the principal imaging modality for ependymomas. $[5,13]$ Computed tomography (CT), which is the main procedure utilized for radiation treatment planning (RTP) purposes may aid in detection of 
calcifications. Expansion of the cord is a critical finding for identification of intramedullary tumors. [5] Ependymomas are typically contrast enhancing lesions visualized as hypointense lesions on T1 weighted MRI sequences and hyperintense lesions on T2 weighted MRI sequences relative to the spinal cord. [5] Heterogeneous signals may result from areas of calcification, necrosis, bleeding, or cystic changes. [5] Myxopapillary ependymomas are mostly found in the conus medullaris region as well defined tumors with uniform contrast enhancement. [5] Contrast enhancement may be variable for anaplastic ependymomas which may have a tendency for infiltration of surrounding tissues, and complete neuroaxis imaging may assist in detection of metastases if present for these high grade tumors. [5] Despite differences in imaging characteristics of ependymomas of different subtypes, imaging based assessments may fail to exactly differentiate between grades for some patients. [5]

Radiation therapy (RT) in the forms of conventionally fractionated RT (CFRT) or radiosurgery as Stereotactic Radiosurgery (SRS), Hypofractionated Stereotactic Radiotherapy (HFSRT), and Stereotactic Body Radiotherapy (SBRT) may be utilized for contemporary management of many CNS disorders as well as several other tumors throughout the human body with encouraging outcomes. [14, 36]

In the context of spinal ependymomas, irradiation may play an integral role in management particularly as a complementary treatment modality. $[5,9,11]$ Definition of treatment volumes for irradiation of spinal ependymomas have been poorly addressed in the literature. In this context, we assessed the incorporation of multimodality imaging with MRI in treatment volume definition for irradiation of spinal ependymomas in this original research article.

\section{MATERIALS AND METHODS}

Irradiation target volume definition based on multimodality imaging with incorporation of MRI or by use of the CT-simulation images only wascomparatively evaluated for patients with spinal ependymoma in this study. Ground truth target volume serving as the reference for actual treatment and comparison purposes was defined by the board-certified radiation oncologists after colleague peer review, collaboration, and ultimate consensus. Informed consents were acquired before treatment.
Thorough evaluationwas performed for lesion size,location, patient symptomatology and preferences along with expected treatment outcomes on an individual basis.

Patient simulation for RTP was performed at CT-simulator (GE Lightspeed RT, GE Healthcare, Chalfont St. Giles, UK)available in our tertiary cancer center. Planning CT images were taken and then transferred to the delineationworkstation (SimMD, GE, UK) for contouring of treatment volumes and critical structures. Either CT-simulation images onlyor fused CT and T1 gadolinium-enhanced MR images were utilized for target volume definition for irradiation. Target determination with CT only and by incorporation of CT-MR fusion was comparatively evaluated. Determination of the ground truth target volume was performed by the board-certified team of radiation oncologists after detailed assessment, collaboration, colleague peer review and ultimate consensus for use in actual treatment as well as for comparison purposes. Treatment delivery was performed by use of the Synergy (Elekta, UK) linear accelerator (LINAC) available at our institution.

\section{RESUltS}

RTPwas performed by theavailable treatment planning system in our institution. Priority was given to achieve optimal target coverage with minimization of normal tissue exposure. Synergy (Elekta, UK) LINAC was used for delivery of treatment.

Irradiationtarget volume determination by CTonly imaging and by CT-MR fusion based imaging was comparatively assessed in the current study. Ground truth target volume outlinedby the board-certified radiation oncologists after detailedevaluation, collaboration, colleague peer review and ultimate consensus was identical to target definition by use of CT-MR fusion based imaging.

\section{DISCUSSION}

Spinal ependymomas are usually low grade tumors following an indolent disease course. Patients may have nonspecific symptoms for a long time before diagnosis. Frequently observed symptoms may include gait disturbances, spasticity in lower limbs, pain, sensory impairments and paresthesias. Tumors located at the lumbar region may cause radicular pain and incontinence which may deteriorate quality of life. 
Surgery and irradiation may be utilized for management of spinal ependymomas. [1-11] While surgery serves as the principal and traditional treatment modality, irradiation may be used as an adjunct therapy or in the setting of recurrences. Selected patients deemed inoperable due to several comorbidities or other conditions may be considered for irradiation in an attempt to provide tumor control and alleviation of symptoms.

Recent years have witnessed huge growth in irradiation capacity of several cancer centers for a wide variety of benign and malign conditions. There have been important advances in the discipline of radiation oncology such as introduction ofadaptive irradiation strategies and contemporary treatment delivery techniques including Image Guided Radiation Therapy (IGRT), Adaptive Radiation Therapy (ART), Intensity Modulated Radiation Therapy (IMRT), Breathing Adapted Radiation Therapy (BART), and stereotactic irradiation with SRS, HFSRT, and SBRT. [37, 43]

Definition of irradiation treatment volumes composes an important aspect of radiotherapeutic management. Avoidance of geopraphical misses and excessive treatment related toxicity are pertinent irradiation goals. While definitionof larger treatment volumes may translate into severe irradiation related toxicity, determination ofsmaller than actual treatment volumes may lead to geopraphical misses with resultant disease progression. Incorporation of multimodality imaging may be usedfor improving the accuracy and precision of target localization, and complementary use of fused CT and MR images may provide improved treatment volume definitionfor irradiation. There is paucity of datain the literature focusing on the usefulness of multimodality imaging for RTPofspinal ependymomas. In this context, ourstudy may add to the literature by suggesting routinized incorporation of MRI into the RTP process to achieve improved outcomesfor patients with spinal ependymomas. Indeed, improvement in treatment volume definition has also been supported bya few other studies in the literature. $[44,57]$

\section{CONCLUSION}

In conclusion, treatment volume determination composes an important part of irradiation for spinal ependymomas. Incorporation of MRI into the treatment volume definition process for precise radiation treatment planning for spinal ependymomas may be utilized to achieve improved outcomes, nevertheless, further study is required to shed light on this critical issue.

\section{REFERENCES}

[1] Hussain I., Parker W. E., Barzilai O. and Bilsky M. H., Surgical Management of Intramedullary Spinal Cord Tumors, Neurosurg. Clin. N. Am.31, 237-249 (2020).

[2] Abdallah A., Emel E., Gündüz H.B., Sofuoğlu Ö.E., Asiltürk M. and Abdallah B.G.,LongTerm Surgical Resection Outcomes of Pediatric Myxopapillary Ependymoma: Experience of Two Centers and Brief Literature Review,World. Neurosurg. 136, e245-e261 (2020).

[3] Chou S.C., Kuo M.F., Lai D.M., Chen C.M., Xiao F., Tsuang F.Y. and Yang S.H, Contemporary management of pediatric spinal tumors: a single institute's experience in Taiwan in the modern era,J. Neurooncol.146, 501-511 (2020).

[4] Sudhan M. D., Satyarthee G.D., Joseph L., Sharma M.C., Kakkar A.and Sharma B.S.,Management and Outcome Analysis of Conus and Filum ependymoma: A Tertiary Center Study, Asian. J. Neurosurg. 14, 821-827 (2019).

[5] Celano E., Salehani A., Malcolm J.G., Reinertsen E. and Hadjipanayis, C.G.,Spinal cord ependymoma: a review of the literature and case series of ten patients.J. Neurooncol. 128, 377-386 (2016).

[6] Kumar R.and Banerjee S., Management and functional outcome of intramedullary spin al cord tumors: A prospective clinical study, Asian. J. Neurosurg. 9, 177-181 (2014).

[7] Voulgaris S., Alexiou G.A., Zigouris A., Fotakopoulos G., Michos $\quad$ E., Katsiafas I., Savvanis G. and Pachatouridis D., Spinal ependymomas: prognostic factors and treatment results, J. Cancer. Res. Ther. 9, 6063 (2013).

[8] McCormick P.C. and Stein B.M., Intramedullary tumors in adults, Neurosurg. Clin. N. Am.1, 609-630 (1990).

[9] McLaughlin M.P., Marcus, R.B. Jr., Buatti J.M., McCollough W.M., Mickle J.P., Kedar A., Maria B. L. and Million R.R.,Ependymoma: results, prognostic factors and treatment recommendations,Int. J. Radiat. Oncol. Biol. Phys.40, 845-850 (1998).

[10] Isaacson S.R.,Radiation therapy and the management of intramedullary spinal cord tumors,J. Neurooncol. 47, 231-238 (2000).

[11] Linstadt D. E., Wara W.M., Leibel S.A., Gutin P.H., Wilson C.B. and Sheline G.E., Postoperative radiotherapy of primary spinal cord tumors,Int. J. Radiat. Oncol. Biol. Phys.16, 1397-1403 (1989). 
[12] Louis D.N., Ohgaki H., Wiestler O.D., Cavenee W.K., Burger P.C., Jouvet A., Scheithauer B.W. and Kleihues P.,The 2007 WHO classification of tumours of the central nervous system,Acta. Neuropathol.114, 97-109 (2007).

[13] Fine M.J., Kricheff I.I., Freed D. and Epstein F.J.,Spinal cord ependymomas: MR imaging features, Radiology.197, 655-658 (1995).

[14] Dincoglan F., Sager O., Uysal B., Demiral S., Gamsiz H., Gündem E., Elcim Y., Dirican B. and Beyzadeoglu M., Evaluation of hypofractionated stereotactic radiotherapy (HFSRT) to the resection cavity after surgical resection of brain metastases: A single center experience,Indian. J. Cancer. 56, 202-206 (2019).

[15] Dincoglan F., Sager O., Demiral S., GamsizH., Uysal B., Onal E., Ekmen A., Dirican B. and Beyzadeoglu M., Fractionated stereotactic radiosurgery for locally recurrent brain metastases after failed stereotactic radiosurgery, Indian. J. Cancer. 56, 151-156(2019).

[16] Demiral S., Dincoglan F., Sager O., Uysal B., Gamsiz H., Ozcan F., Dirican B. and Beyzadeoglu M., Contemporary Management of Meningiomas with Radiosurgery, Int. J. Radiol. Imaging. Technol. 4, 041 (2018).

[17] Dincoglan F., Sager O., Demiral S., Uysal B., Gamsiz H., Dirican B. and BeyzadeogluM., Radiosurgery for recurrent glioblastoma: a review article, Neurol. Disord. Therap.1, 1-5 (2017).

[18] Demiral S., Dincoglan F., Sager O., Gamsiz H., Uysal B., Gundem E., Elcim Y., Dirican B. andBeyzadeoglu M., Hypofractionated stereotactic radiotherapy (HFSRT) for who grade I anterior clinoid meningiomas (ACM), Jpn. J. Radiol.34, 730-737(2016).

[19] Dincoglan F., Beyzadeoglu M., Sager O., Demiral S., Gamsiz H., Uysal B., Ebruli C., Akin M., Oysul K., Sirin S. and Dirican, B.,Management of patients with recurrent gliob lastoma using hypofractionated stereotactic radiotherapy, Tumori.101, 179-184 (2015).

[20] Sager O., Dincoglan F. and Beyzadeoglu M.,Stereotactic radiosurgery of glomus jugulare tumors: current concepts, recent advances and future perspectives,CNS. Oncol. 4, 105-114 (2015).

[21] Gamsiz H., Beyzadeoglu M., Sager O., Demiral S., Dincoglan F., Uysal B., Onal E. and Dirican B.,Evaluation of stereotactic body radiation therapy in the management of adrenal metastases from non-small cell lung cancer, Tumori. 101, 98-103 (2015).

[22] Demiral S., Beyzadeoglu M., Sager O., Dincoglan F., Gamsiz H., Uysal B., Oysul K., Gundem E., Dirican B. and Sirin S., Evaluation of Linear Accelerator (Linac)-Based Stereotactic Radiosurgery (Srs) for the
Treatment of Craniopharyngiomas, UHODUluslararasi Hematoloji-Onkoloji Dergisi. 24, 123-129(2014).

[23] Dincoglan F., Sager O., Gamsiz H., Uysal B., Demiral S., Oysul K., Sirin S., Caglan A. and Beyzadeoglu M.,Management of patients with $\geq 4$ brain metastases using stereotactic radiosurgery boost after whole brain irradiation,Tumori. 100, 302-306 (2014).

[24] Gamsiz H., Beyzadeoglu M., Sager O., Dincoglan F., Demiral S., Uysal B., Surenkok S., Oysul K. and Dirican B., Management of pulmonary oligometastases by stereotactic body radiotherapy, Tumori. 100, 179-183 (2014).

[25] Sager O., Beyzadeoglu M., Dincoglan F., Gamsiz H., Demiral S., Uysal B., Oysul K., Dirican B. and Sirin S.,Evaluation of linear accelerator-based stereotactic radiosurgery in the management of glomus jugulare tumors, Tumori.100, 184-188(2014).

[26] Sager O., Beyzadeoglu M., Dincoglan F., Uysal B., Gamsiz H., Demiral S., Oysul K., Dirican B. and Sirin S.,Evaluation of linear accelerator (LINAC)-based stereotactic radiosurgery (SRS) for cerebral cavernous malformations: a 15year single-center experience, Ann. Saudi. Med. 34, 54-58(2014).

[27] Dincoglan F., Beyzadeoglu M., Sager O., Uysal B., Demiral S., Gamsiz H. and Dirican B.,Evaluation of linear accelerator-based stereotactic radiosurgery in the management of meningiomas: a single center experience,J. BUON. 18, 717-722 (2013).

[28] Sager O., Dincoglan F., Demiral S., Uysal B., Gamsiz H., Dirican B. and Beyzadeoglu M., A concise review of immunotherapy for glioblastoma, Neuroimmunol. Neuroinflammation.5, 25 (2018).

[29] Demiral S., Dincoglan F., Sager O., Gamsiz H., Uysal B., Gundem E., Elcim Y., Dirican B. and Beyzadeoglu M.,Hypofractionated stereotactic radiotherapy (HFSRT) for who grade I anterior clinoid meningiomas (ACM), Jpn. J. Radiol. 34, 730-737(2016).

[30] Demiral S., Beyzadeoglu M., Uysal B., Oysul K., Kahya Y.E., Sager O., Dincoglan F., Gamsiz H., Dirican B. and Surenkok S.,Evaluation of stereotactic body radiotherapy (SBRT) boost in the management of endometrial cancer, Neoplasma. 60, 322-327 (2013).

[31] Sager O., Beyzadeoglu M., Dincoglan F., Demiral S., Uysal B., Gamsiz H., Oysul K., Dirican B. and Sirin, S.,Management of vestibular schwannomas with linear accelerator-based stereotactic radiosurgery: A single center experience, Tumori. 99, 617622(2013). 
[32] Dincoglan F., Sager O., Gamsiz H., Uysal B., Demiral S., Dirican B., Oysul K., Surenkok S., Sirin S. and Beyzadeoglu M., Stereotactic radiosurgery for intracranial tumors: A single center experience, Gulhane. Med. J. 54, 190198(2012).

[33] Dincoglan F., Sager O., Gamsiz H., Demiral S., Uysal B., Surenkok S., Sirin S., Oysul K. and Beyzadeoglu, M., Management of arteriovenous malformations by stereotactic radiosurgery: A single center experience, UHOD- Uluslararasi Hematoloji-Onkoloji Dergisi. 22, 107-112 (2012).

[34] Surenkok S., Sager O., Dincoglan F., Gamsiz H., Demiral S., Uysal B., Sirin S., Oysul K. and Beyzadeoglu M., Stereotactic radiosurgery in pituitary adenomas: A single center experience, UHOD- Uluslararasi Hematoloji-Onkoloji Dergisi. 22, 255-260 (2012).

[35] Dincoglan F., Beyzadeoglu M., Sager O., Oysul K., Sirin S., Surenkok S., Gamsiz H., Uysal B., Demiral S. and Dirican B.,Image-guided positioning in intracranial non-invasive stereotactic radiosurgery for the treatment of brain metastasis, Tumori. 98, 630-635(2012).

[36] Sirin S., Oysul K., Surenkok S., Sager O., Dincoglan F., Dirican B. and Beyzadeoglu M.,Linear accelerator-based stereotactic radiosurgery in recurrent glioblastoma: A single center experience, Vojnosanit. Pregl. 68, 961966 (2011).

[37] Sager O., Beyzadeoglu M., Dincoglan F., Oysul K., Kahya Y. E., Gamsiz H., Uysal B., Demiral S., Dirican B. and Surenkok S., Evaluation of active breathing control-moderate deep inspiration breath-hold in definitive non-small cell lung cancer radiotherapy,Neoplasma. 59, 333-340 (2012).

[38] Uysal B., Beyzadeoğlu M., Sager O., Dinçoğlan F., Demiral S., Gamsız H., Sürenkök S. and Oysul K., Dosimetric evaluation of intensity modulated radiotherapy and 4-field 3$\mathrm{d}$ conformal radiotherapy in prostate cancer treatment,Balkan. Med. J. 30, 54-57 (2013).

[39] Dincoglan F., Beyzadeoglu M., Sager O., Oysul K., Kahya Y. E., Gamsiz H., Uysal B., Demiral S., Dirican B. and Surenkok S., Dosimetric evaluation of critical organs at risk in mastectomized left-sided breast cancer radiotherapy using breath-hold technique,Tumori. 99, 76-82 (2013).

[40] Sager O., Beyzadeoglu M., Dincoglan F., Demiral S., Uysal B., Gamsiz H., Akin M., Gundem E. and Dirican B.,Adaptive splenic radiotherapy for symptomatic splenomegaly management in myeloproliferative disorders, Tumori. 101, 8490 (2015).

[41] Sager O., Dincoglan F., Uysal B., Demiral S., Gamsiz H. and Beyzadeoglu M., Splenic
Irradiation: A Concise Review of the Literature, J. App. Hem. Bl. Tran. 1, 101(2017).

[42] Sager O., Dincoglan F., Uysal B., Demiral S., Gamsiz H., Elcim Y., Gundem E., Dirican B. and Beyzadeoglu M., Evaluation of adaptive radiotherapy (ART) by use of replanning the tumor bed boost with repeated computed tomography (CT) simulation after whole breast irradiation (WBI) for breast cancer patients having clinically evident seroma,Jpn. J. Radiol. 36, 401-406 (2018).

[43] Sager O., Dincoglan F., Demiral S., Uysal B., Gamsiz H., Ozcan F., Colak O., Elcim Y., Dirican B. and Beyzadeoglu M., Breathing adapted radiation therapy for leukemia relapse in the breast: A case report,World. J. Clin. Oncol. 10, 369-374 (2019).

[44] Sager O., Dincoglan F., Demiral S. and Beyzadeoglu M., Radiosurgery Treatment Volume Determination for Brain Lymphomas with and without Incorporation of Multimodality Imaging, Journal of Medical Pharmaceutical and Allied Sciences. 9, 23982404(2020).

[45] Beyzadeoglu M., Dincoglan F., Demiral S. and Sager O., Target Volume Determination for Precise Radiation Therapy (RT) of Central Neurocytoma: An Original Article, International Journal of Research Studies in Medical and Health Sciences 5, 29-34 (2020).

[46] Demiral S., Beyzadeoglu M., Dincoglan F. and Sager O., Assessment of Target Volume Definition for Radiosurgery of Atypical Meningiomas with Multimodality Imaging., Journal of Hematology and Oncology Research. 3, 14-21(2020).

[47] Sager O., Demiral S., Dincoglan F. and Beyzadeoglu M., Target Volume Definition for Stereotactic Radiosurgery (SRS) Of Cerebral Cavernous Malformations (CCMs), Canc. Therapy \& Oncol. Int. J. 15, 555917 (2020).

[48] Dincoglan F., Demiral S., Sager O. and Beyzadeoglu M., Utility of Multimodality Imaging Based Target Volume Definition for Radiosurgery of Trigeminal Neuralgia: An Original Article, Biomed. J. Sci.\& Tech. Res. 26, 19728-19732 (2020).

[49] Sager O., Dincoglan F., Demiral S., Gamsiz H., Uysal B., Ozcan F., Colak O., Dirican B. and Beyzadeoglu M., Evaluation of the Impact of Magnetic Resonance Imaging (MRI) on Gross Tumor Volume (GTV) Definition for Radiation Treatment Planning (RTP) of Inoperable High Grade Gliomas (HGGs), Concepts in Magnetic Resonance Part A, 2019,1-7(2019).

[50] Sager O., Dincoglan F., Demiral S., Gamsiz H., Uysal B., Dirican B. and Beyzadeoglu M., Utility of Magnetic Resonance Imaging (Imaging) in Target Volume Definition for 
Radiosurgery of Acoustic Neuromas, Int. J. Cancer. Clin. Res. 6, 119 (2019).

[51] Demiral S., Sager O., Dincoglan F. and Beyzadeoglu M., Assessment of target definition based on Multimodality imaging for radiosurgical Management of glomus jugulare tumors (GJTs),Canc. Therapy \& Oncol. Int. J.15, 555909(2019).

[52] Dincoglan F., Sager O., Demiral S. and Beyzadeoglu M.,Multimodality Imaging for Radiosurgical Management of Arteriovenous Malformations, Asian Journal of Pharmacy, Nursing and Medical Sciences. 7, 7-12 (2019).

[53] Sager O.,Dincoglan F., Demiral S. and Beyzadeoglu M.,Evaluation of Radiosurgery Target Volume Determination for Meningiomas Based on Computed Tomography (CT) And Magnetic Resonance Imaging (MRI), Cancer Sci. Res. Open Access. 5, 1-4 (2019).
[54] Beyzadeoglu M, Sager O, Dincoglan F. and Demiral S.,Evaluation of Target Definition for Stereotactic Reirradiation of Recurrent Glioblastoma,Arch. Can. Res. 7, 3(2019).

[55] Demiral S.,Sager O., Dincoglan F. and Beyzadeoglu M.,Assessment of Computed Tomography (CT) And Magnetic Resonance Imaging (MRI) Based Radiosurgery Treatment Planning for Pituitary Adenomas, Canc. Therapy \& Oncol. Int. J. 13, 555857 (2019).

[56] Dincoglan F., Sager O., Demiral S. and Beyzadeoglu M.,Incorporation of Multimodality Imaging in Radiosurgery Planning for Craniopharyngiomas: An Original Article, SAJ Cancer Sci. 6, 103 (2019).

[57] Demiral S., Sager O., Dincoglan F., Uysal B., Gamsiz H., Dirican B. and Beyzadeoglu M., Evaluation of Target Volume Determination for Single Session Stereotactic Radiosurgery (SRS) of Brain Metastases, Canc. Therapy \& Oncol. Int. J. 12, 555848 (2018).

Citation: Ferrat Dincoglan, Murat Beyzadeoglu, Selcuk Demiral, Omer Sager Assessment of Treatment Volume Definition for Irradiation of Spinal Ependymomas: an Original Article. ARC Journal of Cancer Science. 2020; 6(1):1-6. DOI:dx.doi.org/10.20431/2455-6009.0601001.

Copyright: (C) 2020 Authors. This is an open-access article distributed under the terms of the Creative Commons Attribution License, which permits unrestricted use, distribution, and reproduction in any medium, provided the original author and source are credited. 